\title{
Factors Affecting Technological Growth in Nigeria and the Way Forward
}

\author{
Isioto Nte Nathaniel", Philip-kpae Friday O., Dickson Rachael \\ Department of Electrical and Electronic Engineering, Ken Sarowiwa Polytechnic, Bori, Port Harcourt, Nigeria
}

Email address:

nnisioto@gmail.com (I. N. Nathaniel)

${ }^{*}$ Corresponding author

\section{To cite this article:}

Isioto Nte Nathaniel, Philip-kpae Friday O., Dickson Rachael. Factors Affecting Technological Growth in Nigeria and the Way Forward. International Journal of Mechanical Engineering and Applications. Vol. 5, No. 5, 2017 pp. 269-274. doi: 10.11648/j.ijmea.20170505.15

Received: May 16, 2017; Accepted: July 11, 2017; Published: October 20, 2017

\begin{abstract}
This paper spotlights Nigeria's technological antecedence and the factors affecting Nigeria's technological growth with a view to proffering solution for a robust technological and industrialized structural framework as a way forward to achieving sustainable technological growth. Majorly, due to relegation of useful indigenous technology as a result of distractions, inability to comprehend what actually is the meaning of technology, inability to identify her appropriate technology and the guiding principle for technology transfer, among others have made it vivid that after over fifty years of independence, Nigeria has been depending, in several areas, on foreign nations for her various technological and industrial needs. This research paper relied majorly on information sources, such as government documents, academic journals and articles, conference papers and personal observations and interactions with people carrying this same burden for Nigeria. From the study, colonialism truncated and hindered improvement in the indigenous skills and techniques of the pre-colonial economy. However, the development of indigenous skills and techniques of pre-colonial Nigeria is a pre-requisite to sound technological growth, rather than depending on foreign inputs, which must be properly monitored and developed to set the pace for Nigeria's industrialization.
\end{abstract}

Keywords: Indigenous Technology, Technology Transfer, Appropriate Technology, Advancement, Industrialization, Development, Appropriate Philosophy

\section{Introduction}

One of the indices by which a nation's growth and advancement can be measured is by her technological endowment and not by the level of her endowment in natural and human resources. A nation's economic efficiency is determined, measured, compared, classified and ranked by its technological advancement. Various authorities have differently defined the term technology.

Technology is derived from the root word "techne" which means activities by which man seeks to adapt to his environment. It is said that technology development pertains to development witnessed through industrial activities [1]. Technology embraces the means by a man controls or modifies his natural environment. It is also seen as a special kind of knowledge which is directed towards practical applications in the physical and social world. It is also defined as the application of practical, mechanical and scientific knowledge to industry and commerce. More so, technology is understood as the body of organized knowledge, tools and machines used by man to manipulate his environment to satisfy his basic needs [2]. Further definition of technology puts it as a systematic application of manufacturing methods and industrial arts to enhance efficiency in human activities. Simply put, technology is defined as the result of man's efforts to do things more efficiently and effectively. Technology is also defined as way or means of accomplishing a task [2, 3]. Summarily, technology can be deduced as the harmonious application of organized scientific, socio-cultural know-how to manipulate the environment with the intention of solving problems and satisfying human need.

Therefore, the traditional skills and techniques used in the production of arts and crafts, blacksmithing, and iron smelting, carding and weaving, brewery among others can be 
summed up as indigenous technology in Nigeria.

Technological advancement entails a process of synchronizing socio-cultural resources, modern and traditional technologies organized together into feasible projects designed to meet specific man's needs and purpose. Hence, the process of textile weaving, spinning and dyeing, ginning carding had been a well-established occupation in pre-colonial Nigeria. Several studies have been done on the traditional skills of the pre-colonial Nigerian, with evidence regarding the positive contribution of indigenous skills and techniques, particularly to the development and growth of various Nigerian communities before colonialism. For example, the Iron technology of the Nok culture around Jos, Bauchi, Daima, Kano and Zaria is dated to about 500 B. C. Archeologists have excavated iron spears and axes at Nok, and iron smelting furnaces had been discovered in Taruga, and it is believed to have contributed to the development of agriculture in the region, while there had been ample evidence regarding the use of iron around the Kanji Dam in the present Niger State of Nigeria, around 2nd century B. C. which had contributed to the building of canoe and other agricultural implements around that region among others [3-5].

Development, on the other hand, is the gradual growth of a skill to become more advanced or the process of producing a more advanced product. Consequently, technology development is the transformation of ideas to practical skills, which are concerned with the production and transformation of raw materials into finished goods.

\section{Methodology}

This research paper relied majorly on information sources, such as government documents, academic journals and articles, conference papers and personal observations and interactions with people carrying this same burden for Nigeria.

\section{Indigenous Technology}

When a technology is sufficiently pure to be composed of the art and artifacts of a society, developed over the years among the people and peculiar to the people, it is referred to as indigenous. It is often an outstanding attribute of the society which is closely linked with specific areas of success in their lives. While indigenous technology can be considered location-specific, its spread will indicate the relatedness among people across a given geographic area. So an indigenous technology may be found among people of common ancestry. For instance, the use of mortar to grind pepper practiced among the Igbos, among others [6]. There no society that is entirely devoid of technology and the dynamism of technology reflects the extent to which the society is open to technological advancement. Notwithstanding, the use of indigenous technology if not subjected to developmental change process, limits the scope of agricultural activity, yield and overall development.

\section{Evidences of Lack of Technological Growth in Any Nation}

Any nation can be seen as suffering from effect of lack of technological growth when viewed against the following checklist.

(1) Is the nation able to produce heavy duty equipment such as tractors, lathe machines, drilling machines, cars, trains, and other equipment for executing her capital projects?

(2) Is she having the technological knowhow to explore and exploit her natural environment or rather depends on foreign technology and expertise to undertake the exploitation of her natural environment?

(3) Does she export her unfinished products to other countries abroad?

(4) Is she dependent on other countries for the supply of her spare parts for industrial machinery?

(5) Is her agriculture mechanized or crude implements are still used for agricultural activities by a large percentage of those who are involved in agricultural production?

(6) Is she able to produce her own military hardware with which to defend herself if the need arises?

A critical examination of Nigeria reveals that all the items on the checklist above are not in the affirmative in this country. Thus, Nigeria as a country has a problem of technological growth as visible from the factors above.

The question now is "what are the reasons responsible for this lack of technological growth in this country? From the study, several factors have been observed as being responsible for the technological underdevelopment in Nigeria, thus to Dekoya [3] affecting the technological growth of the country.

Having identified the problem, it is therefore natural to seek for the way out of the Nigeria's problem of technological growth. The way forward for Nigeria to record remarkable technological growth, is for her to look inward into herself and believe in herself and her resources.

\section{Recognizing the Factors Affecting Nigeria's Technological Growth}

Recognizing issues that are responsible for the problem of technological growth is strategic to attainment of technological emancipation Nigeria deserves. The factors affecting Nigeria's technological growth can be grouped into two, namely, internal and external factors.

\subsection{Internal Factors - Taking an Inward Look}

It has been acknowledged that the attainment of technological growth will depend on the development of strategic industrial policy structure and infrastructural base for the implementation of such policy for global economic competiveness. This will in turn require the development of efficient, accountable, transparent, and participatory 
governance, the creation of strong, efficient, and effective public service institutions to engender government effectiveness, the establishment of a competitive private sector-led business environment characterized by sustained microeconomic stability and the enhancement of national security and improvements in the administration of justice. The following are internal factors bedeviling the economic and technological growth of this country. These are: porous infrastructural base, high index of corruption and internal security.

\subsubsection{Porous Infrastructural Base}

The current infrastructure base in Nigeria is grossly inadequate in terms of capacity and quality and is not capable of catering for the anticipated industrial development. Despite government investments, Nigeria still has huge infrastructure deficits, particularly with regards to power generation. The current power generation capacity is less than 2000 Megawatt, which is about 20 per cent of the estimated national demand. A key challenge for government and the private sector is to build a modern, efficient, and effective infrastructure network within the next five to ten years.

\subsubsection{High Index of Corruption}

Nigeria ranks highly in the Corruption Perception Index. This has implication for investment and the flow of foreign investment into the country. Previous anti-corruption policies implemented in Nigeria have been targeted at enforcement measures rather than addressing the root causes. The root causes of corruption in Nigeria have been identified to include social insecurity and over-centralization of resources at the centre. Even though there are suitable laws and viable institutions to fight corruption in Nigeria, the greatest challenge is in formulating a strategic plan of action to deal with the root causes.

\subsubsection{Internal Security}

The internal security of Nigeria has become a very big challenge in recent times. Internal conflicts, kidnappings, insurgency, including religious, ethnic and economic crisis, have had effects on the economy, most notably by scaring investors from certain parts of the country. Even though insecurity of lives and properties had become noticeable following the civil war and the subsequent military regimes which directly intensified urban violence, the recent upsurge of violence and insurgency in the country heightens the need to comprehensively address the persistent causes of social tension as a risk factor to Nigeria as an investment destination.

\subsubsection{Lack of Purposeful Leadership}

Selfishness or selfish interest on the part of our leaders is a jinx that needs to be broken for Nigeria to record any meaningful technological growth. Yet Government attitude towards breaking the jinx of technological backwardness in Nigeria is laughable. Leaders are easily distracted by their selfishness and quest to amass wealth for themselves and their generation yet unborn. Nigeria is probably the only country in the world where you can find all brands of cars without any one having been designed and made by Nigerians.

\subsubsection{Government Attitude Towards Policy Implementation}

Nigeria had had several national development plans. The first National Development Plan (1962-68), was formally launched in 1962. The Second National Development Plan (1970-74) was launched when Nigeria's newly acquired the status of a major petroleum producing country. The Third National Development Plan (1975-80) was launched at the height of the oil boom. The Fourth National Development Plan (1981-85) coincided with the inception of a global economic recession which sparked declining foreign exchange earnings, balance of payment disequilibrium and unemployment in the Nigerian economy. As a result, the structural adjustment programme (SAP) was adopted in 1986, as an alternative framework for addressing the weaknesses and ineffectiveness of previous development planning efforts [10]. But all these development plans, including the economic transformation agenda, otherwise known as Nigeria Vision 20: 2020 suffered shipwreck because of implementation gap. Generally, lack of adequate implementation on the part of our leadership has been the bane of Nigeria's technological growth.

The Nigeria's Vision 2020 embodies Nigeria's blueprint for an industrial revolution, its aspiration to undergo catchup. The Vision 2020 document predicts that by the year 2020 - some seven years from now - Africa's most populous nation and the world's $6^{\text {th }}$ largest crude oil exporter will have undergone the type of catch-up industrialization that will catapult it into the ranks of the 20 largest global economies. This is realizable if the document will be fully implemented.

In an address to the Nigerian Economic Summit Group [NESG] in October 2008 President Umaru Yar'Adua returned to the Vision 2020 theme, admitting, however, that its realization faces serious constraints posed by a lack of 'purposeful leadership', a definite roadmap and growthinducing environment. This remark, Isioto, Nte. et-al [8] said has already unfolded the problem of lack of implementation to the detriment of this laudable document and subsequently, the possibility of the vision 2020 being a mirage.

\subsubsection{Industrial Policies After Independence}

The Nigeria industrial policies after independence were not vision oriented. For instance, the major industrial policy that Nigeria embarked upon after independence was import substitution industrial (ISI) policy. The major thrust of this policy was:

(1) Building of assembly plants in Nigeria.

(2) Importation of completely knocked down (CKD) parts into Nigeria to be assembled in these plants.

(3) The establishment of steel plants, like Delta Steel Plant and Ajaokuta Steel Plant, and associated foundries that were to produce automobile parts that would be assembled in already established assembly plants.

(4) The establishment of machine tool companies (like 
Oshogbo Machine Tool Company) that were supposed to produce capital goods.

According to Isioto, Nte. et-al [8], the import substitution industrial strategy did not go beyond the stage of building the assembly plants, as the technical partners know that if Nigeria stops importing CKD parts, their companies in Europe would automatically stop production and eventually fold up. It meant that Nigeria would no longer be a market for European.

\subsubsection{Non Involvement of Engineers in Technological Decision Making}

Science and technology researches require the technocrats who have the technical knowhow. Government and decision makers take technological decisions without consulting Nigerian engineers and technologists (through the Nigerian Society of Engineers, NSE) who are the key players in the field of engineering and posses the experience and technical knowhow to contribute towards the effectiveness of any technological developmental decision. [8-10].

\subsection{External Factors}

\subsubsection{Negative Influence Posed by Our Colonial Masters}

The British came to Nigeria among other reason, for economic reason- as a ready market for their sprits, dane guns, mirrors and other goods. Before the advent of colonialism Nigerians were involved in many aspects of industrial and practical arts. They made their own hoes and other implements for farming, etc. According to Akaninwor [7], the colonialists discouraged further development of Nigerian technology as they reasoned it was a threat to the smooth marketing of goods imported from Europe. He went further to assert that "ogogoro" was termed illicit gin by the colonialists, and whoever was caught producing, marketing, or consuming it was frustrated [7].

\subsubsection{Relegation of Indigenous Knowledge}

The advent of modern technology is largely thought by many agricultural experts to have impeded the development of local and indigenous knowledge in the fields of agriculture in Nigeria. The usefulness of this indigenous knowledge (technology) is however all encompassing as it is the basis for agriculture, health care, food preparation, education, environmental conservation and a host of other activities [8]. This in essence means that indigenous technology is the basis of modern technology and should not have been relegated.

\subsubsection{Wrong Philosophy of Western Education}

Western education is the main and proper channel for technological emancipation provided it is built on appropriate philosophy of education. The philosophy of Nigerian education during the colonial period was built on the wrong philosophy as can be confirmed by the statements of Lord Lugard and Rev. J. C. Taylor who said respectively: "The chief function of government primary and secondary schools among primitive communities is to train the more promising boys from the village schools as teachers for those schools, as clerks for the local native courts, and as interpreters:
(Lord Lugard 1921)". "I looked upon them as the commencement of our missionary work. We lost no time and began to teach them the A. B. C." (Taylor 1857)". It is therefore not surprising that apart from the Yaba Higher College that was established in 1947 to produce middle level technical manpower, the colonialist only established secondary schools that were meant to produce clerks, missionaries, and interpreters. The aspect of education which emphasizes skill and practical competence was however not an integral part of the nation's western educational system as at that time [8-10].

\subsubsection{Conflicting Interest in Transfer of Technology}

While the receiver wants technology to bring independence, modernity, and prosperity, the donors do not want receivers to be lifted up but only want to create supplies of what they need and maintain markets for what they produce. For instance some countries did not want Nigeria to have steel mills so as to make Nigeria a dumping ground for steel products.

\subsubsection{Selfishness in Controlling Transfer of Technology}

Technology is usually kept as a preserved property of the donor and thus the exclusive control is vested in them. The donors determine how far and how much the receiver can use the technology by retaining production of spare parts and other components. The technology can only be viable as long as it serves the goal of the donors with little or no concern for the receiver. For instance, provision of tractors for farmers yet they cannot determine when they will have access to it. This is selfishness.

\subsubsection{Transfer of the Appropriate Technology}

The technology that suits one environment may not suit the other. There can even be differences between environments within a country. It is therefore necessary to compare and identify the systems vis a vis the environment and make sure the technology is appropriate for the new environment [12-13].

\section{Discussion and Recommendation}

This research paper has identified many factors militating against the technological growth in Nigeria. This is a necessary prerequisite to proffering solutions to the problem of technological growth and its attendant effects of underdevelopment, unemployment, poverty, youth restiveness, insurgency and dependence on industrialized foreign nations among others.

\subsection{Recommendations for the Way Forward for Technological Growth}

This section outlines the various recommendations, representing a careful research output for the way out of the present technological quagmire evident in the country.

The following recommendations provide the way forward for the technological growth of this nation Nigeria. 


\subsubsection{Copying Items in the Market}

The idea is to buy and knock down products of interest in the workshops, study and analyze each component in the laboratories or workshops developed intentionally for component analysis and for building prototypes of items to be produced. The essence is to ascertain the chemical composition, physical properties and other production parameters of interest and replicate such items.

\subsubsection{Selfless, Determined and Visionary Leadership}

For Nigeria to be technologically developed there must be a leader who is sincere, vision oriented, focused and has Nigeria at heart and devoid of political sycophancy as common with our leaders but with passion for performance. Oluka, S. I et al [2] noted that "the importance of good leadership is nowhere better dramatized than in the case of many underdeveloped countries where provision of capital or technology does not ensure development. The limiting factor in almost every case has been the lack of quality and vigor on the part of managers." This statement is particularly timely for Nigerian leaders whose major aim is not only to amass wealth for themselves but also for their unborn generation.

\subsubsection{Revamp the Steel Industry}

For Nigeria to realize the goal of vision 20: 2020 there is need to revamp steel industries and this will have a positive impact in its economy, thereby creating employment for her citizenry.

\subsubsection{Increase Funding for Our Research and Development Institutes}

To reverse the trend of technological backwardness, Nigeria has to learn from other countries who allocate high percentage of their GDP for research and development (R\&D). A good number of research institutions in Nigeria are not adequately funded. This implies a setback to the effectiveness of research work. According to Ngozi Okonjo-Iweala, as cited by Isioto Nte, N. et-al [8] opined that China has been growing its R\&D expenditure by 20 percent annually, since 1999 . China now accounts for 12 percent of global R\&D expenditure, spending nearly 5 percent of its budget (or 1.76 percent of GDP) in 2010 on the sector. Let's compare this to Nigeria. The Nigerian Engineer [11], revealed that over the past decade, government's S\&T expenditure has been less than 2 percent of the yearly budget (less than 0.3 percent of GDP per year) - a grossly inadequate figure. Nigeria's highest allocation figure was $0.43 \%$ in 1983 , which went down to $0.05 \%$ in 1992 and $0.23 \%$ in 2003 . This is very sad for a sector intended to research into areas that will enhance development in the country.

\subsubsection{Invest into the Educational Infrastructural Facilities}

Investing into the educational infrastructural facilities is investing for the future growth and development of our children and by extension, investing for the future growth and development of technology. If our students cannot do basic practical how can we aspire to a technological breakthrough? It is therefore imperative that for us to overcome the problem of technological backwardness, we (the public and private sectors) must invest monumental resources towards upgrading our educational infrastructures.

\subsubsection{Ensure the Appropriate Technology Transfer}

That America has sent men to space does not mean that Nigeria must also send men to space.

Therefore, we need to embark on the acquisition of the appropriate technology that is relevant and useful to us as a nation. Nigeria as a Nation needs to look inward into her environment to see what her problems are and then exploit the resources in her environment to solve her problems. Nigeria need to develop her indigenous technology $[12,13]$, exploit her environment and fabricate machines tools and equipment that will assist them to do things more efficiently.

\subsubsection{Employ the Technique of Technological Espionage}

Espionage is the systematic use of spies to get technological secrets. This is because such technical and military technology is protected. The secrets can be obtained either by direct investments or through espionage [2], where spies are always engaged to retrieve vital information and company documents required for developing new technology or products, which they pass on to their sponsors for a fee.

\subsubsection{Government Implementation Will-Power}

There are beautiful papers and policies of what to do in the direction of industrialization and technological growth. It is high time they are implemented.

\section{Result and Conclusion}

The economic transformation agenda, otherwise known as Nigeria Vision 20: 2020, sets the direction for the current industrial policy in Nigeria. The industrialization strategy aims to achieve global competitiveness for overall technological growth. This paper has identified various policy issues as well as socio-economic factors that constitute negative influences to the technological growth of Nigeria.

In this paper, an attempt has not been made to empirically test the significance of these variable factors and the level of their impact on the technological growth of Nigeria. However, the recommendations in this paper if judiciously implemented will ensure effective and efficient technology transfer, form a structural framework for technological growth and development, unlock technological growth potentials and serve as a sustainable development blueprint for the nation.

\section{References}

[1] Kayode Joseph Onipede (2010). Technology Development in Nigeria: The Nigerian Machine Tools Industry Experience.

[2] Oluka, S. I et al (2013) Engineer in society, 2nd edition, SNAAP Publishers, Enugu.

[3] Dekoya, A. E. (2012) Technological And Social Change In Agriculture, Published By National Open University of Nigeria. 
[4] Afolabi A. B (2008) Repositioning the Nigerian Economy through Scientific and Technological Innovations. Africa; Journal of Contemporary Issues, 6: 1-8.

[5] Uwaifo V. O. and Uddin P. S. O (2009). Technology and Development in Nigeria: The Missing Link.

[6] Otubanjo F (2005), Education for Underdevelopment. The Nigeria Guardian, October 30.

[7] Akaninwor, G. I. K (2005), Educational Technology (Theory and Practice) Port Harcourt: Wilson Publishing Co.

[8] Isioto, Nte. N, Philip-kpae F. O, Dickson Rachael (2017), Roadmap towards Nigeria's Technological and Industrial Independence. International Journal of Engineering and Emerging Scientific Discovery, Vol. 2, N0. 2, June 2017 (Online) available at http://www.casirmediapublishing.com

[9] Enwere Dike (2010). Vision 2020: Where is the Technological Capability?
[10] Chete L. N. et-al (2016) Industrial development and growth in Nigeria: Lessons and challenges, Nigerian Institute of Social and Economic Research (NISER), Ibadan.

[11] The Nigerian Engineer (2003), Vol. 35 No. 4, December 2003.

[12] Ladipo M. K, Akhuemonkhan I. A, Raimi L. (2013) Technical Vocational Education and Training (TVET) as mechanism for Sustainable Development in Nigeria (SD): Potentials, Challenges and Policy, Journal of Vocational and technical Education.

[13] Paul, C. (2007). A Framework for Understanding Technology and Technological Change." The Public Sector Innovation Journal, Volume 11 (1), Article 3.

[14] Bou-Wen, L. \& Daniel, B. (2001). Factors Affecting Technology Transfer, International Journal of Project Management Volume 19, Issue 5, Pages 287-293. 